\title{
INCIDENCE OF EMERGENCE AGITATION IN PEDIATRIC PATIENT AFTER GENERAL ANESTHESIA
}

\author{
Lucky Andriyanto, Arie Utariani, Elizeus Hanindito, Kohar Hari Santoso, Hamzah, Eka Ari Puspita \\ Department of Anesthesiology and Reanimation, Faculty of Medicine, Universitas Airlangga, Dr Soetomo Hospital, \\ Surabaya, Indonesia
}

\section{ABSTRACT}

Post anesthesia agitation is common problem in pediatric post anesthesia care unit. The incidences range from 10 to $80 \%$. EA has been described as a dissociated state of consciousness in which the child is inconsolable, irritable, and uncooperative typically thrashing, crying, moaning or incoherent. This study was done to determine the incidence of emergence agitation and associated risk factors in pediatric patients who underwent general anesthesia. This descriptive and analytic study was performed on 105 pediatric patient aged 1-12 years that underwent general anesthesia for various elective diagnostic and surgeries at Dr. Soetomo Hospital between January and February 2016. The presence of emergence agitation was recorded using Pediatric Anesthesia Emergence Delirium (PAED) scale. The factors that linked with Emergence Agitation were recorded in a questionnaire. The data were analyzed using SPSS software with logistic regression. p-values less than 0.05 were considered as significant. Forty two (40\%) children had Emergence Agitation. Preoperative anxiety $(p=0.006)$ and Pain $(p=0.035)$ were associated with higher rates of post anesthetic emergence agitation. This study identified preoperative anxiety and pain as risk factors, which are associated with emergence agitation in children. To minimize the incidence of post anesthetic emergence agitation, these risk factors should be considered in the routine care by anesthetist.

Keywords: General anesthesia; pediatric; emergence agitation

\section{ABSTRAK}

Agitasi pada pediatri paska anestesi umum adalah permasalahan yang banyak terjadi di ruang paska anestesi pada anak. Insiden berkisar antara 10-80 \%. EA di deskripsikan sebagai suatu stadium disosiatif di mana anak akan sulit ditenangkan, iritabel, tidak kooperatif, menangis, menendang dan berbicara tidak koheren. Penelitian ini bertujuan untuk menentukan angka kejadian EA dan faktor resiko yang mempengaruhi EA pada pasien pediatri paska anestesi umum. Penelitian ini bersifat deskriptif analitik dengan 105 sampel pasien pediatri usia 1-12 tahun yang menjalani anesthesia umum untuk tindakan pembedahan dan diagnostik di RSUD Dr. Soetomo antara Januari dan Februrari 2016. Kejadian EA ditentukan dengan skala PAED. faktor faktor yang dihubungkan dengan EA direkam dalam suatu kuisioner. Data dianalisa dengan SPSS dengan metode regresi logistik. Faktor yang memiliki nilai $p<0,05$ dinyatakan signifikan. Empat puluh dua (40\%) anak mengalami EA. Kecemasan preoperatif $(p=0.006)$ dan nyeri $(p=0.035)$ secara signifikan berhubungan dengan tingginya kejadian EA. Penelitian ini menemukan kecemasan preoperatif dan nyeri sebagai faktor resiko yang signifikan pada terjadinya EA. Untuk meminimalkan kejadian EA, faktor ini harus diperhatikan oleh setiap ahli anestesi.

Kata kunci: Anestesi umum; pediatri; emergence agitation

Correspondence: Lucky Andriyanto, Department of Anesthesiology and Reanimation, Faculty of Medicine, Universitas Airlangga, Dr Soetomo Hospital, Surabaya, Indonesia. E-mail: 1ky.anest@gmail.com

pISSN:2355-8393 • eISSN: 2599-056x • doi: http://dx.doi.org/10.20473/fmi.v55i1.12546

- Fol Med Indones. 2019;55:25-29 • Received 21 Nov $2017 \bullet$ Accepted 22 Mar 2018

- Open access under CC-BY-NC-SA license • Available at https://e-journal.unair.ac.id/FMI/

\section{INTRODUCTION}

Emergence agitation (EA) is a common problem among postoperative pediatric patients. Emergence agitation, which frequently used interchangeably with emergence delirium (ED) had been defined as a dissociated state of consciousness in which the child is restless, inconsolable, irritable, and uncooperative typically thrashing, kicking, crying, moaning or incoherent. (Jildenstål et al 2014, Vlajkovic \& Sindjelic 2007). Factors can affect agitation after surgery, are age, anxiety, pain, anesthetics, surgery type, perioperative drugs or physiologic compromise and the incidences of EA range from 10 to $80 \%$, (Vlajkovic \& Sindjelic 
2007, Voepel-Lewis et al 2003, Mohkamkar et al 2014). Emergence agitation usually occurs within 30 minutes post anesthesia. Although most of EA resolve spontaneously, it can cause harm to the child such as fall, bleed, self-injury, or parent distress. This descriptive analytical study was done to determine the incidence of emergence agitation and associated risk factors in pediatric patients who underwent general anesthesia.

\section{MATERIALS AND METHODS}

With the approval from ethical committee and parental consent, all healthy 105 children (1-12 yrs. old) underwent general anesthesia for elective surgical or diagnostic procedures in one month and met inclusion criteria were included. All patient should categorized in physical status ASA 1-2, did not have preoperative awareness disturbances, the surgery last less than 30 minutes, severe post operative pain, or sedated and ventilated mechanically after anesthesia. There was no drop out sample in this study. All perianesthesia routine care was performed under supervision of an anesthesiologist. At pre anesthesia period, vital signs, and perioperative anxiety measured using Modified Yale Preoperative Anxiety Scale (mYPAS) were recorded. After induction, induction-score was measured using Induction Compliant Checklist (ICC) scale. Duration of anesthesia, time of awakening were recorded. In recovery room emergence agitation was measured using valid Pediatric Anesthesia Emergence Delirium (PAED) scales at 15 minutes and 30 minutes. The Face-Legs-Activity-Cry-Consolability (FLACCS) scale also measured at the same time. All data recorded was presented by descriptive cross table and correlation of factors influence EA incidences was analyzed by logistic regression.

\section{RESULTS}

105 children aged 1-12 years with ASA class I-II were enrolled over one month (January to February 2016). Characteristic of samples / patients then performed by cross tab (table 1). Age of the sample differ to pre school (1 to 7 yrs. old) age and school age. (7 to 12 years old)

Some of the samples $(66.7 \%, \mathrm{n}=70)$ had preoperative anxiety (mYPAS $>30)$. Almost all of the samples $(93 \%$, $\mathrm{n}=98$ ) premedicated with intravenous midazolam. Induction compliance of the samples was good. $80 \%$ samples $(\mathrm{n}=84)$ had ICC score $=5$.
Duration of anesthesia of samples varies between 0.5 hour to 4.5 hours and the mean of anesthesia duration was 3.6 hours. Time of awakening was duration since anesthetics stopped until the first time the sample could contact with the anesthetist. Most of the sample awake less than 15 minutes $(83.9 \%, \mathrm{n}=88)$. The distribution of time of awakening showed in table 3. Post of pain measured using FLACC scale, and differs in 3 categories. Moderate postoperative pain (FLACC 4-6) was found in $21.9 \%(n=23)$ samples, mild pain (FLACC $1-3)$ found in $31.4 \%(n=33)$ and no pain (FLACC 0) in $46.7 \%(n=49)$.

Table 1. Sample characteristic

\begin{tabular}{|c|c|c|}
\hline $\begin{array}{c}\text { Characteristic of } \\
\text { samples }\end{array}$ & $\begin{array}{c}\text { Number of } \\
\text { Samples }\end{array}$ & $\%$ \\
\hline \multicolumn{3}{|l|}{ Age } \\
\hline Preschool & 67 & 63.8 \\
\hline School & 38 & 36.2 \\
\hline \multicolumn{3}{|l|}{ Sex } \\
\hline Male & 60 & 57.1 \\
\hline Female & 45 & 42.9 \\
\hline \multicolumn{3}{|l|}{ Type of Surgery } \\
\hline $\begin{array}{l}\text { Lower } \\
\text { extremity }\end{array}$ & 9 & 8.6 \\
\hline $\begin{array}{l}\text { Upper } \\
\text { extremity }\end{array}$ & 3 & 2.9 \\
\hline $\begin{array}{l}\text { Head and } \\
\text { neck }\end{array}$ & 26 & 24.8 \\
\hline Abdominal & 12 & 11.4 \\
\hline Burn & 5 & 4.8 \\
\hline Urogenital & 13 & 12.4 \\
\hline Diagnostic & 37 & 35.2 \\
\hline \multicolumn{3}{|l|}{ PS ASA } \\
\hline 1 & 15 & 14.3 \\
\hline 2 & 90 & 85.7 \\
\hline
\end{tabular}

Incidence of emergence agitation (PAED score >10) among samples was high. $40 \%$ of samples $(n=42)$ was had EA. Table 4 presents the relationship between perioperative factors and the presence of EA. Using logistic regression analysis, it was founded that perioperative anxiety $[(\mathrm{p}<0.05$ (OR: 4.188 , CI $95 \%$ $(1.5-11.6)]$ and postoperative pain [ $(\mathrm{p}<0.05$ (OR: 1.797 , CI $95 \%$ (1.0-3.1)] had significant correlation with the presence of emergence agitation among samples.

\section{DISCUSSION}

This study found the incidence of emergence agitation (PAED > 10) in pediatric patient who underwent elective surgery was $40 \%$. PAED scale is reliable and valid tool to measure the presence of emergence agitation, and 10 was the most specific and sensitive cut of point. (Sikich 
\& Lerman 2004). This incidence was higher than the result found by Voepel-Lewis et al. 2003 and Mohkamkar et al. 2014 that was $18 \%$ and $17.9 \%$. But our result was still in range $10-80 \%$ as the finding of some studies. (Nasr \& Hannalah 2011).

Some studies shows some perioperative factors that correlated to emergence agitation are post-operative pain, short time awaking, anesthetic drugs as well as site of operation. (Mohkamkar et al. 2014; Singh et al. 2012; Voepel-Lewis et al. 2003). Our finding shows perioperative factors that correlated to the incidence of emergence of agitation were perioperative anxiety $[(\mathrm{p}<0.05 \quad(\mathrm{OR}: 4.188, \quad \mathrm{CI} \quad 95 \% \quad(1.5-11.6)] \quad$ and postoperative pain $[(\mathrm{p}<0.05$ (OR : 1.797 , CI $95 \%(1.0-$ 3.1)].

Our study used Modified Yale Preoperative Anxiety Scale (mYPAS) as a tool to assess perioperative anxiety of the patients. It was measured in preparation area by anesthesiologist when the parents was still accompany the patient. mYPAS scale measured by attending anesthesiologist was accurate to assess perioperative e anxiety (Maclaren et al. 2010). Study by (Kain et al. 2004) shown that marked increase in mYPAS score correlated linearly to the increase of emergence agitation.

Pain was proven as a factor correlated to the incidence of EA. Some studies showed that anesthesia for non painful procedures with sevoflurane anesthesia has higher incidence of EA than the same procedures with halothane or propofol. These findings suggest that EA/ED may be a clinical phenomenon that is separate from pain. (Vlajkovic \& Sindjelic 2007, Mohkamkar et al 2014) In this study we excluded patients with severe pain (FLACCS >7). Severe pain was the most confounding variable when assessing a child's behavior upon emergence because of the overlapping clinical picture with EA/ED. (Vlajkovic \& Sindjelic 2007) (Mohkamkar et al. 2014). Adequate pain management would reduce incidence of EA but would not eliminated completely. (Mohkamkar et al 2014).

In our study age, physical status, induction score, type of surgery and time of awakening not statistically significant correlated to emergence agitation.

Aside to concern some predictor factor, it is important to take steps to prevent EA. The role of premedication of midazolam as an EA preventive measure remains a matter of debate. Intravenous administration of midazolam just before the end of surgery proved to reduces emergence agitation (Lee \& $\mathrm{Ph}$ 2015). Intravenous anesthesia with propofol mixed with ketamin or injection of propofol mixed with ketamin before completion of anesthesia also showed that EA incidence was lower than control group. (Rizk \& Samir 2014; Anghelescu et al. 2011). But other study showed that the concurrent use of midazolam or propofol did not reduce the incidence of emergence agitation but did delay emergence and recovery (Cohen et al. 2002). Fentanyl and dexmedetomidine injection before end of surgery also shown reduces EA. (Abdelhalim \& Alarfaj 2013, Makkar et al 2016).

Emergence agitation management includes nonpharmacological and pharmacological approaches. Non-pharmacological approaches include measures to ensure comfort and safety of patients such as motivation, elution, sling that can be done by health workers and parents. The most common pharmacological approach is the administration of midazolam, propofol and opioid such as fentanyl. (Wong \& Bailey 2015)

Table 2. Perioperative factors

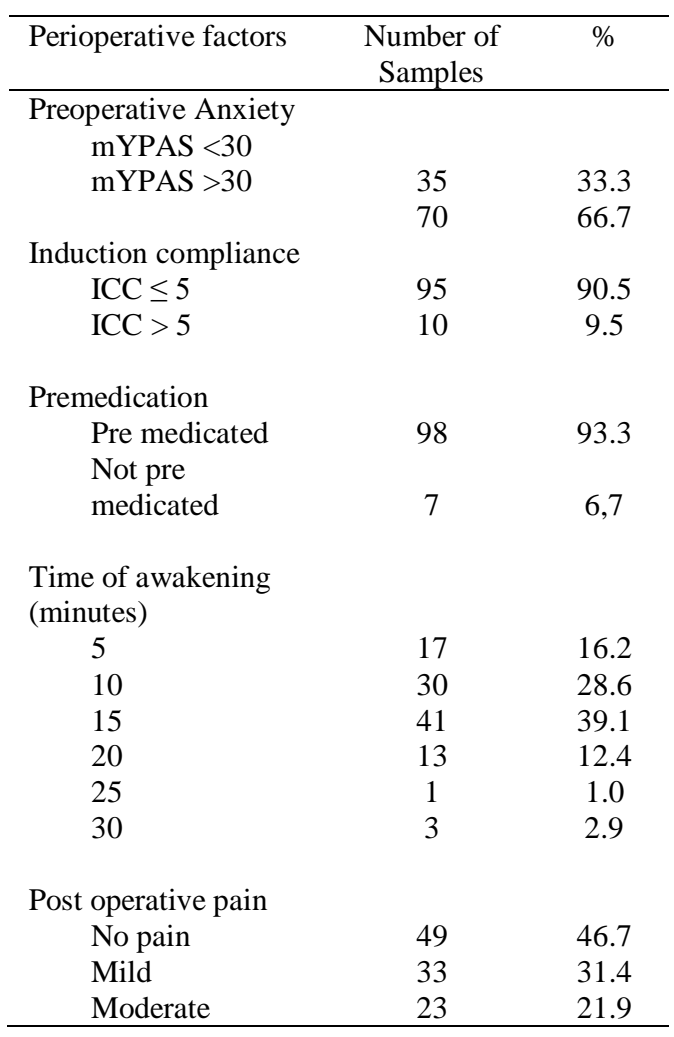

Table 3. Incidence of emergence agitation

\begin{tabular}{lcc}
\hline Emergence Agitation & $\begin{array}{c}\text { Number of } \\
\text { Samples }\end{array}$ & $\%$ \\
\hline No EA & 63 & 60 \\
EA & 42 & 40 \\
\hline
\end{tabular}


Table 4. incidence of emergence agitation relative to perioperative factors

\begin{tabular}{|c|c|c|c|c|}
\hline Variable & EA & $\%$ & $\mathrm{p}$ Value & $\begin{array}{c}\text { Relative risk (95\% } \\
\text { CI) }\end{array}$ \\
\hline Perioperative Anxiety & & & 0.006 & $4.188(1.5-11.6)$ \\
\hline mYPAS $<30$ & 36 & 85.7 & & \\
\hline mYPAS $>30$ & 6 & 14.3 & & \\
\hline Post operative pain & & & 0.035 & $1.797(1.0-3.1)$ \\
\hline No pain & 14 & 33.3 & & \\
\hline Mild & 13 & 31 & & \\
\hline Moderate & 15 & 35.7 & & \\
\hline Age & & & 0.868 & NA \\
\hline Preschool & 14 & 33.3 & & \\
\hline School & 28 & 66.7 & & \\
\hline Physical status & & & 0.134 & NA \\
\hline 1 & 3 & 7.1 & & \\
\hline 2 & 39 & 92.9 & & \\
\hline Induction compliance & & & 0.253 & NA \\
\hline $\mathrm{ICC} \leq 5$ & 35 & 83.3 & & \\
\hline $\mathrm{ICC}>5$ & 7 & 16.7 & & \\
\hline Type of surgery & & & 0.932 & NA \\
\hline Lower extremity & 5 & 11.9 & & \\
\hline Upper extremity & 0 & 0 & & \\
\hline Head and neck & 11 & 26.2 & & \\
\hline Abdominal & 7 & 16.7 & & \\
\hline Burn & 3 & 7.1 & & \\
\hline Urogenital & 5 & 11.9 & & \\
\hline Diagnostic & 11 & 26.2 & & \\
\hline Time of awakening & & & 0.557 & NA \\
\hline 5 & 5 & 11.9 & & \\
\hline 10 & 13 & 31 & & \\
\hline 15 & 16 & 38.1 & & \\
\hline 20 & 5 & 11.9 & & \\
\hline 25 & 0 & 0 & & \\
\hline 30 & 3 & 7.1 & & \\
\hline
\end{tabular}

\section{CONCLUSION}

This study has found the incidence of emergence agitation among pediatric patient who underwent elective surgery was $40 \%$. Perioperative factors that correlated to the presence of emergence agitation were preoperative anxiety and postoperative pain. Thus anesthetist should consider these risk factors in anesthesia routine care.

\section{REFERENCES}

Abdelhalim A, Alarfaj A (2013). The effect of ketamine versus fentanyl on the incidence of emergence agitation after sevoflurane anesthesia in pediatric patients undergoing tonsillectomy with or without adenoidectomy. Saudi Journal of Anaesthesia 7, 392

Anghelescu DL, et al (2011). Prevention of emergence agitation in seven children receiving low-dose ketamine and propofol total intravenous anesthesia. AANA Journal 79, 238-242

Cohen IT, Drewsen S, Hannallah RS (2002). Propofol or midazolam do not reduce the incidence of emergence agitation associated with desflurane anaesthesia in children undergoing adenotonsillectomy. Paediatric Anaesthesia 12, 604609

Jildenstål PK, et al (2014). Routines for reducing the occurrence of emergence agitation during awakening in children, a national survey. SpringerPlus 3, 572

Kain ZN, et al (2004). Preoperative anxiety and emergence delirium and postoperative maladaptive behaviors. Anesthesia and Analgesia 99, 1648-1654

Lee HW, Ph D (2015). Midazolam with placebo on prevention of emergence agitation in children having strabismus surgery. 1354-1361

Maclaren JE, et al (2010). Prediction of preoperative anxiety in children: Who is most accurate? 108, 17771782 
Makkar JK, et al (2016). A comparison of single dose dexmedetomidine with propofol for the prevention of emergence delirium after desflurane anaesthesia in children. Anaesthesia 71, 50-57

Mohkamkar M, et al (2014). Postanesthetic emergence agitation in pediatric patients under general anesthesia. Iranian journal of pediatrics 24, 184-90

Nasr VG, Hannalah RS (2011). Emergence agitation in children a review. Mid. East J. Anaesthesiol 21, 17582

Rizk SN, Samir EM (2014). Use of ketofol to control emergence agitation in children undergoing adenotonsillectomy. Egyptian Journal of Anaesthesia 30, 13-19

Sikich N, Lerman J (2004). Development and psychometric evaluation of the pediatric anesthesia emergence delirium scale. Anesthesiology 100, 11381145

Singh R, et al (2012). Comparative evaluation of incidence of emergence agitation and post-operative recovery profile in paediatric patients after isoflurane, sevoflurane and desflurane anaesthesia. Indian Journal of Anaesthesia 56, 156-161

Vlajkovic GP, Sindjelic RP (2007). Emergence delirium in children: Many questions, few answers. Anesthesia and Analgesia 104, 84-91

Voepel-Lewis T, Malviya S, Tait AR (2003). A prospective cohort study of emergence agitation in the pediatric postanesthesia care unit. Anesthesia \& Analgesia, 1625-1630

Wong D, Bailey C (2015). Emergence delirium in children. Anaesthesia 70, 375-392 